\title{
Constraints and prospects of carp production in Rajshahi and Natore districts, Bangladesh
}

\author{
A B M Mohsin ${ }^{1 *}$, MN Islam ${ }^{2}$, MA Hossain ${ }^{2}$ and SM Galib ${ }^{1}$ \\ ${ }^{1}$ Department of Fisheries, University of Rajshahi, Rajshahi-6205, Bangladesh \\ ${ }^{2}$ Department of Zoology, University of Rajshahi, Rajshahi-6205, Bangladesh
}

\begin{abstract}
This study was conducted in Rajshahi and Natore districts of northern area of Bangladesh for a period of three years (2007 to 2009). One hundred carp ponds were selected randomly and fish farmers were interviewed to reveal the existing constraints and prospects. Ten percent farmers reported multiple ownership as a problem and 16\% farmers stated that lease value of pond is too high which reducing their profit level. Lack of quality fish seeds was reported by 33\% farmers which results in low growth and high mortality of fishes. Nine percent carp farmers reported that inorganic fertilizers were not giving expected performances. Thirty three percent carp farmers failed to apply required inputs in due time due to lack of sufficient credit. Plankton bloom was recorded in $18 \%$ ponds. Three percent fish farmers were found to be affected by flood and drought. Eight percent farmers reported non-severe attack of disease. Fish poaching and poisoning were revealed as major constraints. Thirty six percent farmers mentioned lack of technical supports. Due to found constraints, the farmers failed to use inputs and experiences properly resulted in unsatisfactory fish production $(3598.72 \pm 785.83 \mathrm{~kg} / \mathrm{ha} / \mathrm{yr})$ to the carp farmers. Further research efforts are recommended to assess the specific impacts of recorded constraints on fish production.
\end{abstract}

Key words: Carp polyculture, carp production, aquaculture constraints, fish farmers.

\section{Introduction}

Fisheries is one of the major components of agricultural activities in Bangladesh and plays a vital role in nutrition, employment, income generation and foreign exchange earnings (Bhuiyan et al., 2011). Carp polyculture is the most popular form of aquaculture practice in Rajshahi and Natore districts. Though there are at least 265 freshwater fish species in the country (Rahman, 2005) but only 4 native and 12 exotic carp species are cultured in Bangladesh (DoF, 2012). Some non-carp species are also brought under culture lately in the country. The total amount of cultured fishes in the country is produced in ponds and ditches (86\%) and other water bodies (14\%) (FRSS, 2009). Among the fishes produced in ponds and ditches, $88.18 \%$ are carp species and $11.82 \%$ are non-carp species (FRSS, 2009). Average fish production (2839 kg/ha) in aquaculture ponds and ditches of Bangladesh is still much lower than many other carp producing countries like China (4474 kg/ha) (FRSS, 2009; Dey et al., 2005). Though the aquaculture production rate has been increased much in recent time in Bangladesh, but still not satisfactory in comparison to most other Asian countries due to existence of some constraints and problems in culture system. To increase the production, we need to identify the existing constraints and problems first. But in Bangladesh, research on this issue is not satisfactory. The present study was conducted with a view to identifying the existing problems and constraints of carp culture.

\section{Materials and Methods}

Study sites and duration: Field survey was carried out in Rajshahi and Natore districts, situated in the northern part of Bangladesh, for a period of three years from 2007 to 2009 .

Sampling framework: A total of 100 carp polyculture ponds were selected randomly in the study areas. Pond operators of those ponds i.e. carp farmers were interviewed with a selected questionnaire to reveal the existing problems and constraints of fish production. The questionnaire was prepared, pre-tested in field situation and then necessary modifications were made prior to final data collection.

Data analyses: All the collected data were tabulated, and subjected to common analyses by MS Excel.

\section{Results and Discussion \\ Existing problems and constraints}

Various constraints and problems of carp culture recorded in the study areas are mentioned here under different headings. All the recorded constraints are displayed in figure 1. 


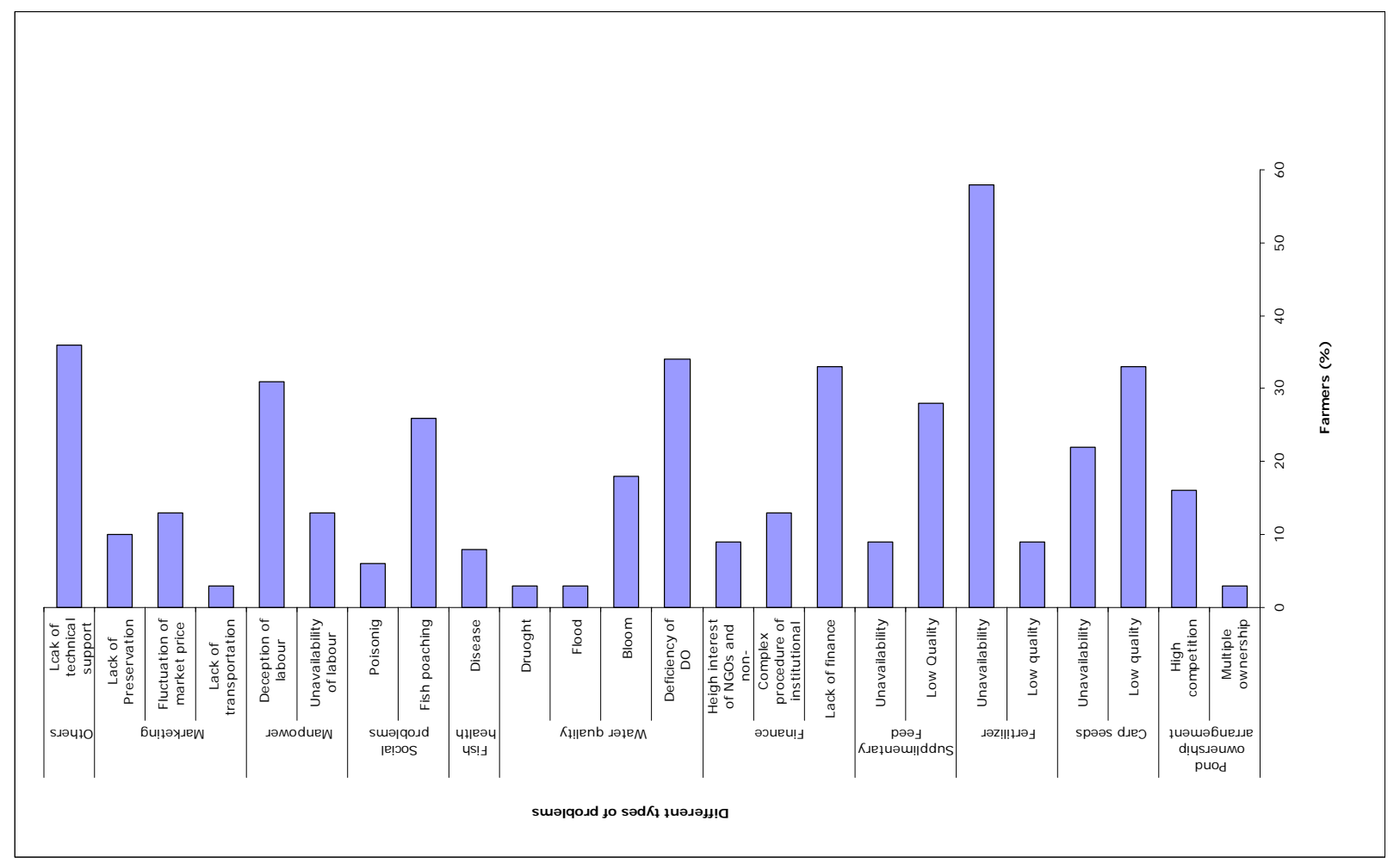

Fig. 1: Constraints of carp culture in the study area

Ownership problems: A few farmers (10\%) reported multiple ownership of the culture pond as a problem in the study areas. Respondents have mentioned that multiple-ownership of pond was a vital problem in study areas in past, and they were trying to avoid this problem by leasing out the pond. However $16 \%$ farmers stated that lease value of pond was too high which reduced their level of profit. However, multiple-ownership of water bodies is a well documented constraint for aquaculture in Bangladesh (Mollah et al., 1990; Bhuiyan, 1999; Alam, 2005).

Input problems: Lack of quality fish seeds was reported by $33 \%$ farmers which resulted in low growth and high mortality of fishes. Almost all the farmers preferred wild seeds than that of hatchery seeds to avoid these problems, but unavailability of wild seeds in due time was also mentioned by $22 \%$ farmers. Hossain et al. (2008) stated that healthy fish seeds are the prerequisite for fish production. 10\% farmers stocked both wild and hatchery produced carp seeds into their ponds. Similar findings were also reported by Mohsin and Haque (2009), Alam (2005), Awal et al. (2001), Khaleque et al. (1998), Hossain et al. (1991) and Khan et al. (1991).
Nine percent carp farmers reported that inorganic fertilizers were not giving expected outputs. They have suspected that these fertilizers were impure. Moreover supply of fertilizers, especially inorganic fertilizers, was not regular in the study areas. 58\% farmers reported unavailability of desired fertilizers when needed which greatly affected their production. Similar findings were also reported by Ahmed et al. (1995).

All the farmers mentioned high price of commercial carp supplementary feeds. To minimize the feeding cost local farmers were interested to use locally available low cost fish feed ingredients like rice bran, wheat bran, oil cakes etc. But mixture of other particles to these feed ingredients was reported by $28 \%$ farmers, which resulted in low performances of ingredients. Moreover, unavailability of these ingredients when needed was found in case of $9 \%$ farmers. Mohsin and Haque (2009) mentioned similar findings in his research work.

Credit problem: Thirty three percent carp farmers failed to apply required inputs, fertilizers and feeds, in due time due to lack of sufficient credit. In this case, loan from the bank or other organizations may be an alternative. But, difficulties in getting loan from government banks 
were mentioned by $13 \%$ farmers. However loan from non-government organizations was easy to get but interest rate was high. Present findings are similar to the findings of Alam (2005). Sayeed et al. (2007) mentioned that our farmers do not have enough money to invest in aquaculture.

Water quality problems: Thirty four percent farmers reported that their stock grasped at the water column due to lack of sufficient dissolved oxygen (DO) level in pond water. All the farmers did not use any water quality test kit. While facing this problem, the farmers followed traditional methods to increase DO level, like swimming in pond to agitate water.

Plankton bloom was recorded in $18 \%$ fish ponds. Over fertilization of pond, especially with organic fertilizers, was responsible for this and this problem was common in winter season. This result was similar to Sayeed et al. (2007) who mentioned that fish farmers use fertilizers at different doses, sometimes three to four times more than that of standard dose.

Carp farmers of the study areas were also affected by natural disasters like flood and drought. $3 \%$ fish farmers were found to be affected by flood and drought. During flooding, farmers tried to create barricade with 'bana' and nets to restrict fish from escaping. Effects of drought were common in small sized ponds and they farmers placed water hyacinth as a shelter in the deeper part of pond to shelter the fish stock. Islam (1986) mentioned that $13 \%$ farmers were suffering from sufficient water in dry season.

Fish disease: Eight percent fish farmers reported that disease has been affected their stock, but the attack was not severe. High stocking density during winter season was found as the prime cause of disease which was similar to the result of Hossain et al. (2008). According to FFP (2004), $30 \%$ fish farmers treated fish disease as a major problem. Whereas Mohsin and Haque (2009) described disease as minor problem in their study.

Social problems: Fish poaching was a severe problem in the study areas and $26 \%$ farmers have been victimized by this problem. To overcome this problem, farmers placed bamboo or tree branches into the pond water. Security guards have also been employed in some cases too. $6 \%$ farmers were the victim of fish poisoning. This was an important risk of aquaculture in the study areas. Similar findings were also reported by Alam (2005) and Islam (1986).
Manpower problems: Thirty one percent farmers mentioned deception of labour as a problem. They have also mentioned high rate of daily labour. 13\% farmers reported unavailability of labour timely.

Marketing problems: Problem of slow transportation to fish market was reported by $3 \%$ farmers. For which the farmers have to sell their fishes in the nearest fish markets and was not getting expected price. Fluctuation of market price was treated as problem by $13 \%$ farmers. Lack of proper preservation facilities was also mentioned by $10 \%$ farmers.

Others: Thirty six percent fish farmers stated that they were not getting technical supports from relevant government or non-government organizations and they had to discuss with neighbor farmers to solve their problems. Positive relationship between level of knowledge and fish production has been reported by Rahman et al. (1989) and Hossain et al. (1991). According to Islam (1986) some fish farmers have basic information regarding pond aquaculture but they have no scientific knowledge about technologies. Pekar et al. (2002) mentioned that better knowledge of functioning of aquaculture ecosystems would help to improve the management of culture sustain high pond productivity.

\section{Prospects of carp polyculture}

The carp polyculture in ponds of Rajshahi and Natore districts was a common aquaculture practice and the most important means of animal protein production for local people. The minimum, maximum and mean $( \pm S D)$ fish production was found $2017.65,5458.88$ and $3598.72 \pm 785.83$ $\mathrm{kg} / \mathrm{ha} / \mathrm{yr}$ respectively. According to Sayeed et al. (2007), fish production can be increased up to $5000 \mathrm{~kg} / \mathrm{ha}$ by feeding and fertilization which is much higher than that of the mean production. This indicates that there is enough scope of increasing the existing production. Due to found constraints, the farmers failed to use inputs and experiences in culturing fish properly. Farmers said that due to mentioned constraints overall fish production rate was not satisfactory and they did not get expected profits. They also believed that these constraints would badly affect the aquaculture production in future.

Emphasis should be given on expansion of hatchery facilities to supply high quality fish seeds required to support high aquaculture production in the study area. Similar comment also made by Bhuiyan et al. (2011). Several problems (e.g. 
plankton bloom) can easily be avoided by maintaining standard doses of fertilizers. This not only helps to control the bloom, but also reduce the input cost resulting in more profit.

The production of aquaculture in a unit area is poor comparing to other neighboring countries (Sayeed et al., 2007). This may be due to presence of so many problems. Further research efforts are necessary to understand the specific impacts of recorded constraints on fish production.

\section{References}

Ahmed, M., Rab, M.A. \& Gupta, M.V. 1995. Impact of improved aquaculture technologies: results of an extension programme on the farming system of Bangladesh. Asian Fish. Sci. 8(1): 27-39.

Alam, M.S. 2005. Integrated farming systems- a way to increase farmer's income and to a better environment. Ph.D. Thesis, Department of Fisheries, University of Rajshahi, Rajshahi, Bangladesh, 185 pp.

Awal, M.A., Ali, M.A. \& Mia, M.G.F. 2001. Fisheries resources and utilization patterns in some selected areas of Jamalpur and Sherpur district. Bangladesh Journal of Training and Development 14(1, 2): 183-190.

Bhuiyan, A.K.M.A. 1999. Closed waterbody fisheries: management issue and future strategies. In: National Workshop on Community Based Fisheries Management and Future Strategies for Inland Fisheries in Bangladesh. Keynote paper. 24-25 October 1999. Dhaka, Bangladesh, $19 \mathrm{pp}$.

Bhuiyan, A.S., Akther, S. \& Aktar, N. 2011. Present status and fish seed production of the hatcheries of six upazilas of Rajshahi District. Univ. J. Zool. Rajshahi Univ. 30: 29-32

Dey, M.M., Paraguas, F.J., Bhatta, R., Alam, F., Weimin, M., Piumsombun, S., Koeshandrajana, S., Dung, L.T.C. \& Sang N.V. 2005. Carp production in Asia: Part treands and present status. In: Carp Genetic Resources for Aquaculture in Asia (Eds. Penman, D.J.; Gupta, M.V. and Dey, M.M.). WorldFish Center, Penang, Malaysia, 152 pp.

DoF. 2012. National Fish Week 2012 Compendium. Department of Fisheries, Ministry of Fisheries and Livestock, Dhaka, Bangladesh. 144 pp. (in Bengali).

FFP. 2004. PRA impact study on batch 2 fisheries villages of the aquaculture extension and training component. Internal Studies Report No. 15. Fourth Fisheries Project, Department of Fisheries, Dhaka, Bangladesh, 41 pp.
FRSS. 2009. Fisheries Statistical Yearbook of Bangladesh 2007-2008. Fisheries Resources Survey System, Department of Fisheries, Ministry of Fisheries and Livestock, Dhaka, Bangladesh, 42 pp.

Hossain, M.D., Hossain, M.K., Rahman, M.H., Akter, A. and Khanom, D.A. 2008. Prevalence of ectoparasites of carp fingerlings at Santaher, Bogra. Univ. J. Zool. Rajshahi Univ. 27: 17-19.

Hossain, M.I., Mirza, M.J.A. \& Miah, M.A.M. 1991. Management aspects practiced by the fish farmers. Bangladesh Journal of Training and Development 4(2): 15-24.

Islam, M.S. 1986. Constraints and recommendations for pond fish aquaculture. Bangladesh Journal of Extension Education 1(2): 53-60.

Khaleque, M.A., Akand, M.R.I., Masud, A.K.M.S. \& Islam, A.K.M.S. 1998. Survey of fisheries resources in some selected thanas under Netrokona district. Bangladesh $\mathrm{J}$. Fish. 21(2): 35-39.

Khan, M.S., Quddus, M.A. \& Islam, M.A. 1991. A study of pond hatchery resources in Trishal upazila. Bangladesh $\mathrm{J}$. Extension Education 6(1\&2): 55-64.

Mohsin, A.B.M. \& Haque, E. 2009. Effects of constraints on carp production at Rajshahi district. Bangladesh. J. Fish. Int. 4(2): 30-33.

Mollah, A.R.; Chowdhuty, S.N.I. \& Habib, M.A.B. 1990. Input output relations in fish production under various pond size, ownership pattern and constraints. Bangladesh Journal of Training and Development 3(2): 15-17.

Pekar, F., Be, N.V., Long, D.N., Cong, D.T. \& Olah, J. 2002. Eco-technological analysis of fish farming households in the Mekong Delta of Vietnam. In: Rural Aquaculture (Eds. P. Edwards, D.C. Little and H. Demaine), CABI Publishing, UK, 77-95.

Rahman, A.K.A. 2005. Freshwater Fishes of Bangladesh, second edition, Zoological Society of Bangladesh, Dhaka, Bangladesh, $394 \mathrm{pp}$.

Rahman, M.M., Hossain, M.A., Miah, M.A.M. \& Rahman, M.M. 1989. An investigation into fisheries knowledge of fish farmers towards fish culture management. Bangladesh Journal of Training and Development 1(1): 9-16.

Sayeed, M.A., Alam, M.T., Sultana, S., Ali, M.S., Azad, M.S. \& Islam, M.A. 2007. Effect of inorganic fertilizer on the fish growth and production in polyculture system of Bangladesh. Univ. J. Zool. Rajshahi Univ. 26: 77-80. 